\title{
Construction proposal of hydraulic equipment designed to test hydraulic components and energy carriers
}

\author{
Jozef Nosian ${ }^{1, *}$, Marietta Markiewicz ${ }^{2}$, Romana Janoušková ${ }^{3}$ and Patrícia Feriancová ${ }^{3}$ \\ ${ }^{1}$ Slovak University of Agriculture, Department of Machine Design, 94976 Nitra, Slovakia \\ ${ }^{2}$ UTP University of Science and Technology, Faculty of Mechanical Engineering, 85-796, \\ Bydgoszcz, Poland \\ ${ }^{3}$ Slovak University of Agriculture, Department Transport and Handling, 94976 Nitra, Slovakia
}

\begin{abstract}
The aim of the present article is the construction of a device for measuring and testing hydrostatic converters and subsequent verification measurement of the proposed device. This device will allow the measurement and testing of hydraulic pumps under laboratory conditions. In our case, we will test the hydraulic pump UD-25R, which is used in hydraulic drives of agricultural machines. Last but not least, the device described in the article can be used to test individual energy carriers used in hydraulic systems. The described device can simulate conditions that occur in operation. Using verification measurements we have proved that the designed laboratory equipment is suitable for testing hydraulic components and also allows monitoring and testing of the properties of individual hydraulic fluids. The measurement will result in a change in flow rate over time.
\end{abstract}

\section{Introduction}

Hydraulic devices are widely used in all areas of industry, mainly for their advantages. The biggest benefits of hydraulic mechanisms include: transmission of energy over long distances, high performance, simplicity, reliability and a relatively long life. Current development and modernization in the field of hydraulic mechanisms is mainly aimed at reducing energy consumption and increasing the power that these machines are capable of transmitting. Last but not least, the development of these mechanisms focuses on their environmentally friendly operation, ie that these mechanisms will minimize contamination of the environment. It is very important that hydraulic components and energy carriers are tested under laboratory conditions before being put into practice. There are high requirements of hydraulic fluids that serve as energy carriers in hydraulic systems. Their producers must consider their demands for quality improvement and simultaneously reducing the burdening of environment [1]. A comprehensive analysis of the effect of biological fluids and mixtures thereof has already been performed by Puškár et al. [2]. Before their first use in operation, fluids must be subjected to laboratory tests to prevent or minimize risk of damage of expensive agriculture machinery. A specially designed laboratory device observing the operating conditions of machine is used for this purpose [3]. The need for agricultural machinery to be tested from the point of view of their suitability to agricultural use will grow continuously because these machines directly affect agricultural production [4]. The measurement of hydraulic devices used in industry was also dealt by authors Simikič et al. , Zastempowski and Hujo et al. [5, 6, 7].

\section{Material and methods}

* Corresponding author: xnosian@uniag.sk 


\subsection{The determination of the individual components of a hydraulic device}

The determination of the individual components of a hydraulic device for assessing the operation of the hydraulic pumps and energy carries are based on relations from author Hujo et al. [3].

Wall thickness of a pipe:

where:

$$
s=\frac{p_{\max } \cdot d_{p}}{2 \cdot \delta} \cdot k
$$

$\mathrm{p}_{\max }-$ max. pressure, $\mathrm{MPa}$

$\mathrm{d}_{\mathrm{p}}$ - inner surface, $\mathrm{m}^{2}$

$\delta$ - ultimate tensile strength, $\mathrm{Pa}$

where:

$$
d_{p}=\sqrt{\frac{4 \cdot Q}{\pi \cdot w}}
$$

$Q-$ flow rate, $\mathrm{dm}^{3}$.rpm

$\mathrm{W}$ - resistance to flow rate, $\mathrm{m} / \mathrm{s}$

Cooling power:

Specific cooling power:

$$
P_{0}=P_{01} \cdot 1.1
$$

where:

$$
P_{01}=\frac{P_{V}}{T_{1}-T_{2}}
$$

$\mathrm{P}_{\mathrm{v}}$ - cooling power, $\mathrm{W}$

$\mathrm{T}_{1}-$ max. temperature, ${ }^{\circ} \mathrm{C}$

$\mathrm{T}_{2}-$ min. temperature, ${ }^{\circ} \mathrm{C}$

Based on the presented calculations we were able to determine the basic parameters of the experimental laboratory equipment. The calculated values are shown in Table 1 . We were able to determine further necessary data on the basis of calculations. Based on the data from the catalog, we were able to select other required components with the characteristics and parameters necessary for commissioning the laboratory equipment (Table 1).

Table 1. The basic parameters of experimental laboratory equipment.

\begin{tabular}{|c|c|}
\hline Parameter & Value \\
\hline Oven wall thickness (min.) & $1.21 \mathrm{~mm}$ \\
\hline Inner surface (min.) & $9.86 \mathrm{~mm}^{2}$ \\
\hline Cooling capacity (min.) & $0.1215 \mathrm{~kW} /{ }^{\circ} \mathrm{C}$ \\
\hline $\begin{array}{c}\text { Specific Cooling } \\
\text { Performance (min) }\end{array}$ & $0.1165 \mathrm{~kW} /{ }^{\circ} \mathrm{C}$ \\
\hline Pipe diameter (d) & $14 \mathrm{~mm}$ \\
\hline Wall Thickness (s) & $1.5 \mathrm{~mm}$ \\
\hline Tank Capacity (V) & $80 \mathrm{dm}^{3}$ \\
\hline
\end{tabular}

When operating an experimental device for measuring and diagnosing the operation of hydraulic pumps and hydraulic fluids, heat is formed in the hydraulic circuit. This is why a cooler is installed on the device. Cooler is used to heat dissipation the hydraulic circuit. In our case it is an EMMEGI cooler type $20124 \mathrm{~K} \mathrm{230-400.} \mathrm{We} \mathrm{chose} \mathrm{this} \mathrm{cooler} \mathrm{based} \mathrm{on}$ calculations. The cooler performance is $\mathrm{P}_{0}=0.2 \mathrm{~kW} /{ }^{\circ} \mathrm{C}$. According to the above 
calculations, this power is sufficient to cool the hydraulic circuit. The evaluation of hydraulic fluids in dependence on temperature and pressure was dealt with by Kopiláková et al. [8] and Kosiba et al. [9]. Both authors found that the operating parameters, mainly temperature and pressure, affect the working fluid and affect subsequent measurements. On Figure 1 it is possible to see a diagram of an experimental hydraulic device for measuring and testing hydraulic pumps and energy carries. The equipment can be used to measure and test various hydraulic pumps and hydraulic fluids. Figure 1 shows a device for measuring and testing hydraulic pumps and energy carriers. From Figure 1 we see that the device consists of two circuits, namely circuit A (left side) and circuit B (right side). These two circuits are separated by a mechanical coupling (MC). Circuit A and circuit B practically consist of the same components to simulate the same conditions in both circuits. One part of the circuit is used to test and examination a hydraulic pump with a tilting plate (circuit A). The second part of the circuit is used to test and diagnose the rotary gear pump. This gear pump has external toothing (circuit B). Each circuit has a separate tank. This makes it possible to test two different types of hydraulic fluids. Filters are placed on the tanks. The filters are used to filter out dirt from hydraulic oil. As in any hydraulic circuit, a safety valve must also be fitted in this circuit. Each circuit has its own safety valve, in our case both safety valves are set to maximum possible pressure of $20 \mathrm{MPa}$. After exceeding this pressure value, the safety valve releases the oil from the hydraulic circuit back into the tank. UD 25 is a one-way gear pump from Jihostroj Aero Technology and HydraulicsUD-25R is most commonly used in agriculture, specifically in ZETOR tractors and most often in a ZETOR Forterra tractor. The technical parameters of the hydraulic pump are given in Table 2.

Table 2. The basic parameters of experimental laboratory equipment.

\begin{tabular}{|c|c|c|}
\hline Parameter & Unit & Value \\
\hline Rated speed & \multirow{3}{*}{$\min ^{-1}$} & 1500 \\
\hline Maximum speed & & 3000 \\
\hline Minimum speed & & 500 \\
\hline Maximal pressure at the inlet & \multirow{2}{*}{$\mathrm{MPa}$} & 0.05 \\
\hline Minimum inlet pressure & & 0.03 \\
\hline Nominal outlet pressure & \multirow{2}{*}{$\mathrm{MPa}$} & 20 \\
\hline Maximum outlet pressure & & 23 \\
\hline Geometric volume & $\mathrm{cm}^{3}$ & 25 \\
\hline Maximum oil viscosity & \multirow{2}{*}{$\mathrm{mm}^{2} \cdot \mathrm{s}^{-1}$} & 1200 \\
\hline Minimum oil viscosity & & 10 \\
\hline Maximum oil temperature & \multirow{2}{*}{${ }^{\circ} \mathrm{C}$} & 80 \\
\hline Minimum oil temperature & & -20 \\
\hline
\end{tabular}




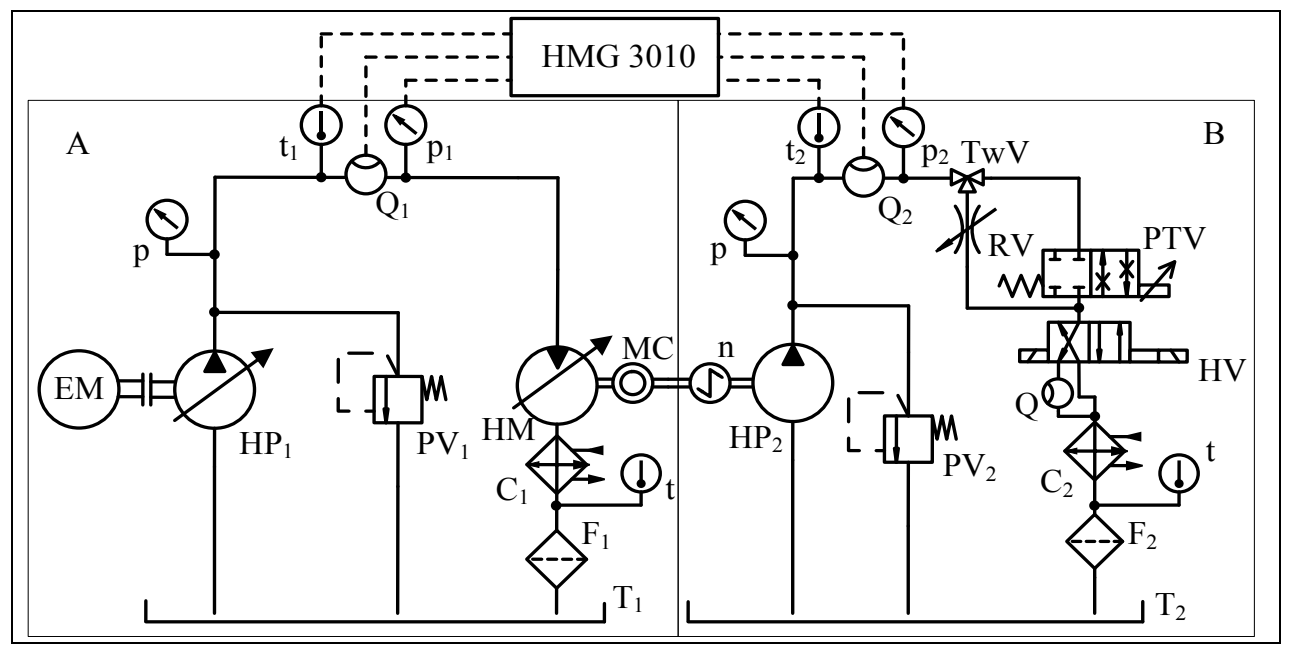

Fig. 1. Kinematic scheme of hydraulic circuit. Legend: (A - primary circuit, B - secondary circuit, $\mathrm{EM}$ - electromotor, $\mathrm{HP}_{1}$ - regulatory hydraulic pump, $\mathrm{PV}_{1}, \mathrm{PV}_{2}$ - pressure valve, $\mathrm{p}$ - manometer, $\mathrm{t}_{1}$, $\mathrm{t}_{2}$ - temperature sensor ETS 4148-H-006-000, $\mathrm{Q}_{1}, \mathrm{Q}_{2}$ - flow sensor EVS 3108-H-0300-000, $\mathrm{p}_{1}, \mathrm{p}_{2}-$ pressure sensor HDA 4748-H-0400-000, Q - volume flowmeter, $\mathrm{t}$ - temperature gauge, HM regulatory hydromotor, $\mathrm{HP}_{2}$ - gear hydraulic pump, $\mathrm{RV}$ - reducing valve, $\mathrm{HV}$ - hydraulic valve, PTV - proportional throttle valve, $\mathrm{TwV}$ - three-way valve, $\mathrm{MC}$ - mechanical coupling, $\mathrm{n}$ - rpm sensor ISP $308 \mathrm{~S} 01 \mathrm{~N}, \mathrm{~F}_{1}, \mathrm{~F}_{2}-$ filter, $\mathrm{T}_{1}, \mathrm{~T}_{2}-$ tank).

Part A is used to drive and control circuit B. EM is an electric motor that is used to convert electrical energy into mechanical energy. This electric motor replaces a combustion engine, which is commonly used in hydraulic pump drive machines. The mechanical energy with the electric motor is converted by the hydraulic pump $\mathrm{HP}_{1}$ into the pressure energy in the hydraulic circuit. At the top we have the HMG 3010, which is used to monitor the values. In our case, the device monitors temperature, pressure, and flow. It records and stores the monitored values in its memory. The HMG 3010 is connected to pressure, temperature and flow sensors. In both circuits we have installed safety valves $\mathrm{PV}_{1}$ and $\mathrm{PV}_{2}$ and filters $F_{1}$ and $F_{2}$. As already mentioned, heat is generated when passing the liquid through the circuit. This heat is an undesirable effect and therefore both circuits need to be cooled using $\mathrm{C}_{1}$ and $\mathrm{C}_{2}$ coolers. The cooler maintains a constant temperature of $\mathrm{t}=40{ }^{\circ} \mathrm{C}$. Dilatation thermometers are located in both tanks to monitor the hydraulic oil temperature. Both hydraulic circuits have their own tank $\mathrm{T}_{1}$ and $\mathrm{T}_{2}$. So we can have two types of oils in the device at the same time. One type of oil in one tank and another type of oil in the other tank. The HM hydraulic motor is used to convert the pressure energy generated by the $\mathrm{HP}_{1}$ hydraulic pump into mechanical energy. The hydraulic motor is connected to the $\mathrm{HP}_{2}$ hydraulic pump via the $\mathrm{MC}$ coupling. The $\mathrm{HP}_{2}$ hydraulic pump is a gear pump and converts mechanical energy into pressure energy in the B circuit. This part of the circuit is largely identical to circuit A. PTV is used to increase the hydraulic pump load. Using a proportional throttle valve, we can simulate the pressures that are achieved when operating a machine used in practice. The TwV three-way valve is used to change the selected hydraulic pump load method. When the reduce valve is used, it changes the pump flow and also changes the pressure in the hydraulic circuit. The flow change process can be controlled by a solenoid, using a PTV proportional throttle valve. A second alternative that serves to verify the flow characteristics of a hydraulic pump is to use a volume flow meter. Flow control through the flow meter is controlled by a two-position hydraulic valve HV. The two-position switch switches to the working fluid flow sensing position and is measured exactly $t=60 \mathrm{~s}$. After the measurement, the flow characteristic of the hydraulic 
pump is obtained. Thanks to this characteristic we are able to verify the functionality of the hydraulic pump connected in the laboratory equipment. The circuit also includes manometers $(P)$, pressure sensors $\left(\mathrm{p}_{1}\right.$ and $\left.\mathrm{p}_{2}\right)$ and temperature sensors $\left(\mathrm{t}_{1}\right.$ and $\left.\mathrm{t}_{2}\right)$ for temperature and pressure monitoring. The laboratory testing device allowed to simulate variable testing condition to simulate the real agricultural wheel tractor operational condition. The flow properties of the hydraulic pump with tested hydraulic fluid [10]. The measurement results in a change in flow and pressure on the time.

\section{Results}

\subsection{Laboratory measurements}

The laboratory equipment consists of two separate circuits. Proportional (PTV) resp. the throttle valve (TrV) is used to exerting a load in the circuit. This load simulates operating pressures. Thrust valve loads have been used by their authors Hujo et al. [3] and Kosiba et al. [11] in their laboratory hydraulic devices. Thanks to the construction, we can also install another type of hydraulic pump into the circuit. The verification measurement was carried out in the laboratory of the Department of Transport and Handling, of the Faculty of Engineering of the Slovak University of Agriculture in Nitra. Verification measurements were made at $1500 \mathrm{rpm}$. The output of these measurements was the flow of the hydraulic pump. Based on the measurements, we created a graph (Figure 2, Figure 3).

\subsection{Flow rate and flow efficiency of the hydraulic pump}

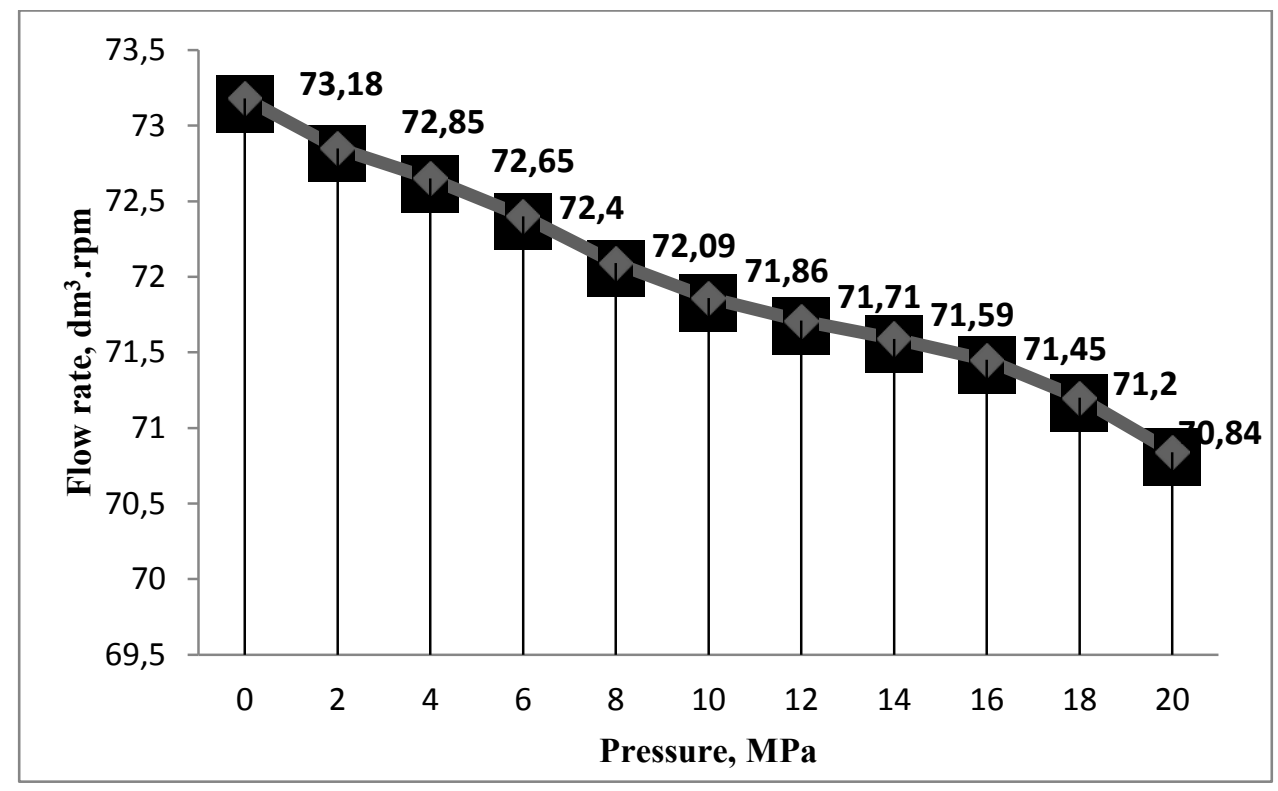

Fig. 2. Flow characteristic of the hydraulic control pump. 


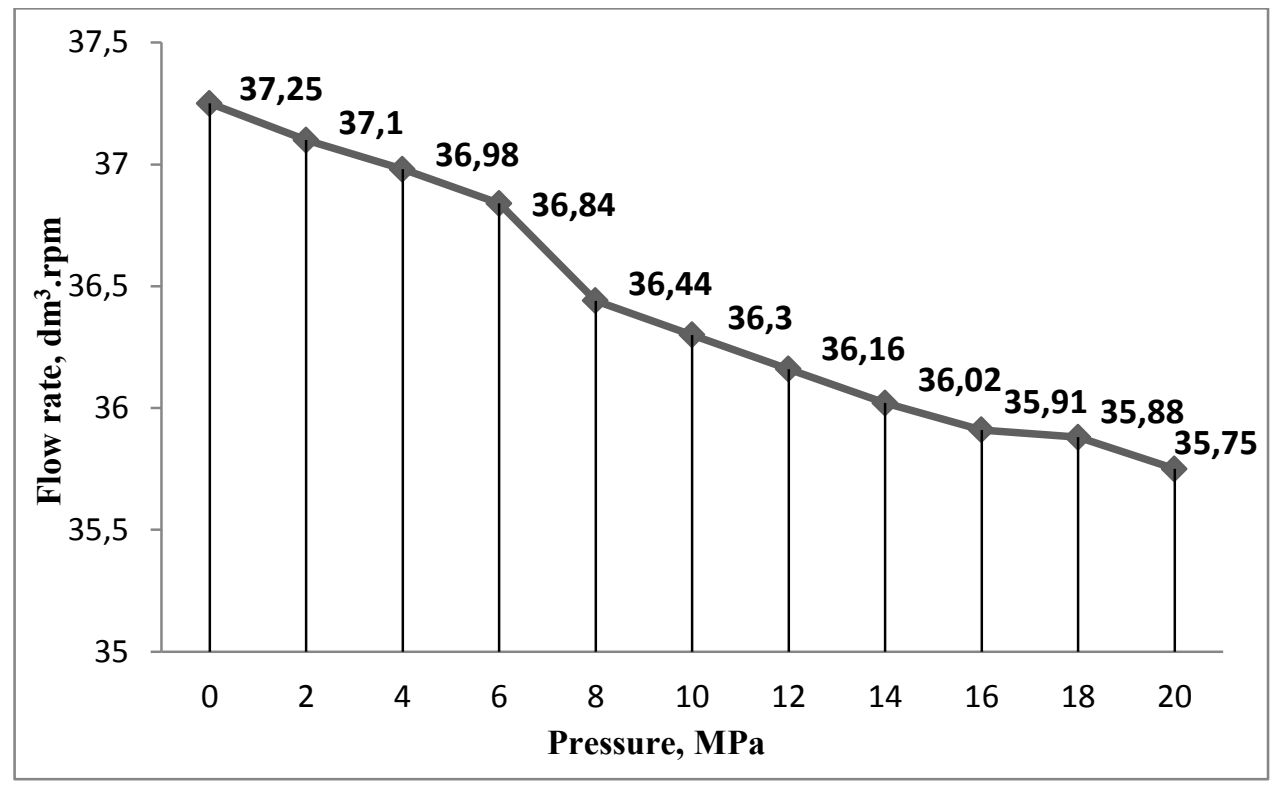

Fig. 3. Flow characteristic of hydraulic gear pump.

Flow efficiency of hydraulic pump (Figure 4, Figure 5) will be calculated form the measured flow characteristic:

where:

$$
\eta_{p}=\frac{Q}{V_{G} \cdot n} \cdot 100
$$

$V_{G}$ - geometrical volume of hydraulic pump, dm3 $n$ - nominal speed of hydraulic pump, rpm

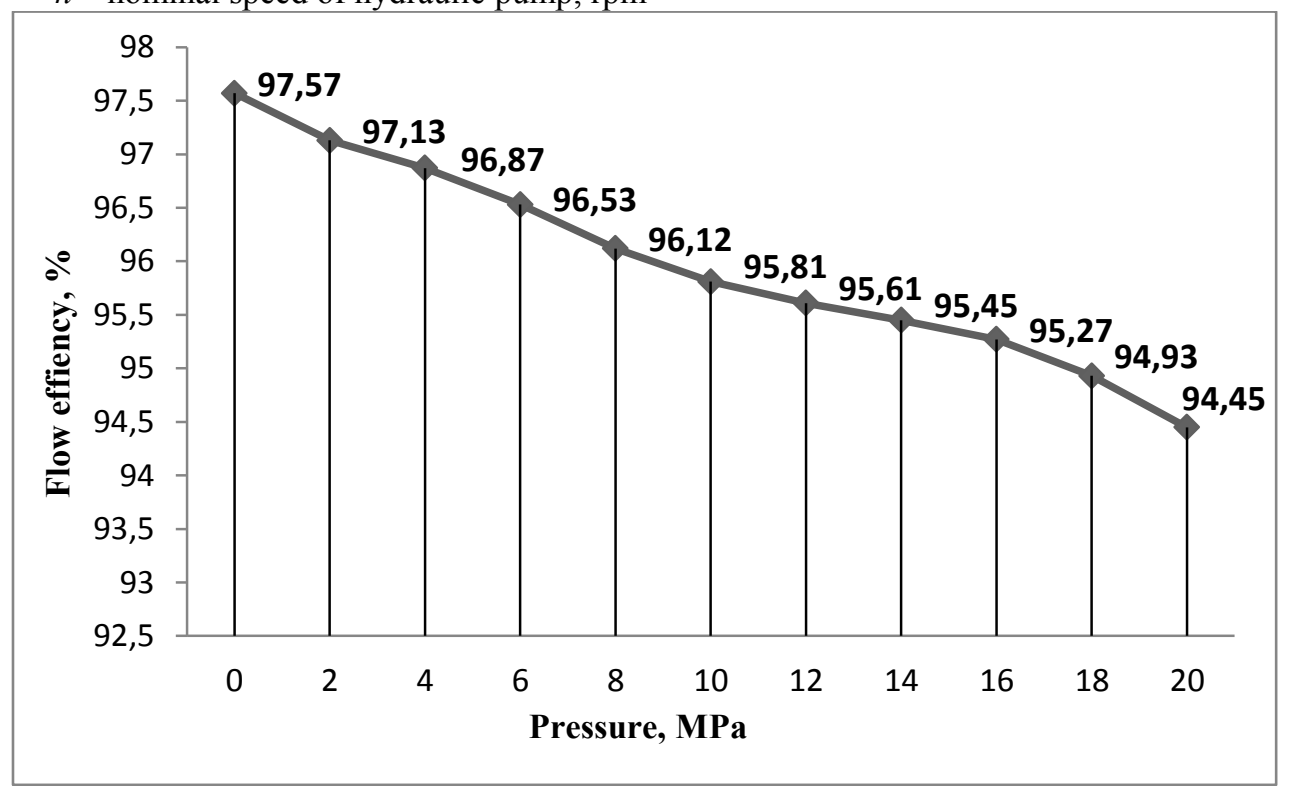

Fig. 4. Flow efficiency of the regulating hydraulic pump. 


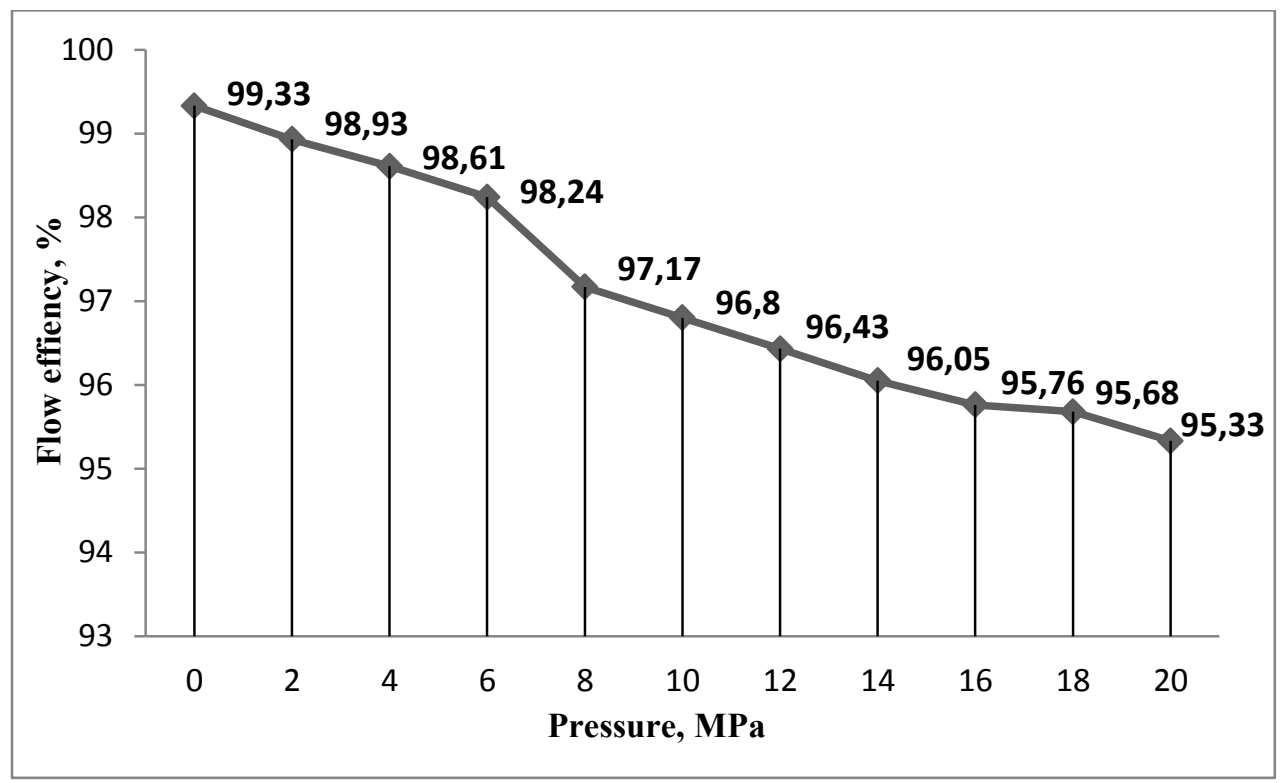

Fig. 5. Flow efficiency of the gear hydraulic pump.

With correct data analysis and correct interpretation of data we can create very precise results [12]. During the verification measurement, we were able to record the flow values of the gear hydraulic pump (circuit B), at a pressure $p=0 \mathrm{MPa}$ and a rotation speed $n=1500$ $\mathrm{rpm}$. Thanks to these values we were able to determine the flow efficiency of the hydraulic pump based on the calculations. In this case, we calculated the efficiency $\eta_{\mathrm{pp}}=99.33 \%$. By changing the pressure during the measurement, $p=20 \mathrm{MPa}$, we calculated the flow efficiency $\eta_{p p}=95.33 \%$. In circuit $A$, in the regulatory pump circuit, we recorded a flow efficiency of $\eta p p=97.57 \%$ at a pressure of $p=0 \mathrm{MPa}$ and at a speed of $\mathrm{n}=1500 \mathrm{rpm}$ and at pressure $\mathrm{p}=20 \mathrm{MPa}$ we noticed $\eta p \mathrm{p}=94.45 \%$.

Reducing the flow efficiency of the hydraulic pump relative to the increasing pressure corresponds to the results of the work of authors Kosiba et al. [11] and Tulík et al. [13]. On the basis of the theoretical processing of the authors Hujo et al. [7] and Kosiba et al. [9] it is possible to determine the coefficient of loss of liquid $k_{Q}$, which affects the resulting liquid flow.

Displacement gear pumps:

where:

$$
q=2 . z_{m}\left(V_{1}-V_{\text {loss }}\right)=2 \cdot z_{m}\left[\frac{n}{360} \pi \cdot r_{a 1}^{2}-\int f\left(x_{0}, y_{0}\right) d x-V_{s t r}\right]
$$

$\mathrm{Z}_{\mathrm{m}}$ - number of tooth gaps,

$\mathrm{V}_{1}$ - volume of tooth gap, $\mathrm{m}^{3}$

$\mathrm{n}$ - rotation speed, $\mathrm{rpm}$

$\mathrm{V}_{\text {loss }}$ - loss volume, $\mathrm{m}^{3}$

$\mathrm{r}_{\mathrm{a} 1}$ - radius of the gearhead, $\mathrm{m}$

Loss volume:

$$
V_{s t r}=\int_{x_{j 1}}^{x_{j 2}}\left[f\left(x_{2}, y_{2}\right)-f\left(x_{1}, y_{1}\right) d x\right]
$$

where:

$\mathrm{f}\left(\mathrm{x}_{2}, \mathrm{y}_{2}\right)$ a $\mathrm{f}\left(\mathrm{x}_{1}, \mathrm{y}_{1}\right)$ - gear rotation function

Resulting Loss Flow Ratio:

$$
k_{Q}=\frac{Q_{\max }-Q_{\min }}{\bar{Q}}
$$


where:

$\mathrm{Q}_{\max }-$ maximum flow of fluid, $\mathrm{m}^{3} \cdot \mathrm{s}^{-1}$

$\mathrm{Q}_{\min }-$ minimum flow of fluid, $\mathrm{m}^{3} \cdot \mathrm{s}^{-1}$

Resulting Loss Flow Ratio:

where:

$$
k_{Q}=\frac{Q_{\max }-Q_{\min }}{\bar{Q}}
$$

$\mathrm{Q}_{\max }-$ maximum flow of fluid, $\mathrm{m}^{3} \cdot \mathrm{s}^{-1}$

$\mathrm{Q}_{\min }-$ minimum flow of fluid, $\mathrm{m}^{3} \cdot \mathrm{s}^{-1}$

\section{Conclusion}

Hydraulic equipment is widely used in agricultural machinery. Thus, it is very important to design a device that would allow testing and diagnosis of hydraulic components under laboratory conditions. The described device can test and measure hydraulic pumps as well as energy carriers. Recently, more and more emphasis has been placed on ecological liquids, therefore there is a need to design a device that would allow testing of ecological liquids. In view of high ecotoxicity and low biodegradability, mineral oil-based lubricants constitute a considerable threat to the environment [14]. Therefore, it is necessary to examine the idea of the possible harmfulness of agricultural machinery on the environment [15]. The analysis of operating fluids was dealt with by authors Čornák [16] and Tkáč [17]. The main requirement for the equipment was to simulate as much as possible the actual hydraulic circuit of the agricultural machine. The proposed device facilitates testing of hydraulic pumps and individual energy carriers used in hydraulic systems. Based on the verification measurement, we have shown that the device described in the article can be used for measuring and testing hydraulic pumps and energy carriers.

This work was supported by project VEGA 1/0155/18 „Applied research of the use of ecological energy carriers in agricultural, forestry and transport technology.“

This work was supported by project KEGA 028SPU-4/2019 „Practical utilization of design and testing knowledge of transmission systems of hydraulic mechanisms of mobile agricultural and forestry machinery."

This work was supported by project APVV SK-PL-18-0041 „The development of scientific cooperation in the study of the effects of biofuels in road transport, including environmental impact."

\section{References}

1. J. Rusnák, M. Kadnár, M. Kučera, Biologicky odbúratel'né oleje z pohl'adu ich tribologických vlastností. SPU Nitra, 85 (2009)

2. M. Puškár, A. Jahnátek, I. Kuric, J. Kádárová, M. Kopas, M. Šoltésová, Air Qual., Atmos. Health, 12, 7 (2019)

3. L. Hujo, P. Kangalov, J. Kosiba, Laboratory test devices for evaluating the lifetime of tractor hydraulic components. University "Angel Kanchev" of Ruse, 69 (2015)

4. L. Hujo, J. Jablonický, Z. Tkáč, Návrh inovatívneho laboratórneho simulačného zariadenia na skúšanie hydrostatických prevodnikov a hydraulických kvapalín. SPU Nitra. 140 (2017)

5. M. Simikič, N. Dedovič, L. Savin, M. Tomič, O. Ponjičan, Soil Till. Res., 141, 32-43 (2014)

6. M. Zastempowski, Journal Res. Appl. in Agrc. Engineering, 58, 2 (2013)

7. L'. Hujo, Z. Tkáč, J. Tulík, J. Kosiba, D. Uhrinová, M. Jánošová, RAE, 62, 1 (2016)

8. B. Kopiláková, J. Turza, L. Hujo, J. Kosiba, Tribology in industry, 39, 129-135 (2017)

9. J. Kosiba, Š. Čorňák, J. Glos, J. Jablonický, V. Vozárová, A. Petrovič, J. Csillag, Agronomy Research, 14, 5 (2016) 
10. L. Hujo, Š. Čorňák, Z. Tkáč, M. Jánošová, In 7th Intern. conf. on trends agric. engineering. Prague, Czech Republic, 183-188 (2019)

11. J. Kosiba, Z. Tkáč, L. Hujo, B. Stančík, I. Štulajter, RAE, 59, 27-33 (2013)

12. I. Kuric, I. Zajačko, M. Císar, Adv. in Scie. and Techn. Research journal, 10, 32 (2016)

13. J. Tulík, L. Hujo, B. Stančík, P. Ševčík, Journal of Central Euro. Agric., 14, 4 (2013)

14. M. Kučera, Z. Aleš, Z. Ivandič, L. Hujo, Journal of Central Euro. Agric., 14, 4 (2013)

15. Z. Tkáč, L. Hujo, J. Tulík, J. Kosiba, D. Uhrinová, V. Šinský, Acta Universitatis Agriculturae et Silviculturae Mendelianae Brunensis, 62, 5 (2014)

16. Š. Čorńák, In 17th Intern. Scie. Conference Engi. for Rural Develo., Jelgava, Latvia, 2048-2053 (2018)

17. Z. Tkáč, Š. Čorňák, V. Cviklovič, J. Kosiba, J. Glos, J. Jablonický, R. Bernát, ATA, 20, 2 (2017) 